\title{
Leapfrogging in Marketing: Empirical Analysis of Kenyan Mobile Phone Industry
}

\author{
Mae Chepkoech ${ }^{*}$, Charles Lagat ${ }^{2}$, Gary L. Frankwick ${ }^{3}$ \\ ${ }^{1,2}$ School of Business \& Economics, Moi University, Kenya \\ ${ }^{3}$ College of Business Administration, University of Texas El Paso, U.S.A \\ * Corresponding author: chepkoecchmae@yahoo.com
}

\begin{abstract}
Article History
Received 2021-06-12

Revised 2021-07-12

Accepted 2021-07-13

Published 2021-07-15
\end{abstract}

\section{Keywords}

Leapfrog marketing

Perceived product quality

Switching cost urgency to consumer

leapfrogging

\section{How to cite?}

Chepkoech, M., Lagat, C., \& Frankwick,

G. L. Leapfrogging in Marketing:

Empirical Analysis of Kenyan Mobile

Phone Industry. SEISENSE Journal of

Management, 4(4), 33-46. doi:

10.33215 /sjom.v4i4.665
Purpose: This paper aims to analyze the concept of leapfrogging in the mobile phone industry in the Republic of Kenya.

Design/Methodology: The study adopted a cross-sectional research design, stratified and simple random sampling techniques in collecting data from 349 respondents picked from a population of 15506 employees of three Cosmopolitan County Governments in Kenya.

Findings: Outcome indicates that; perceived product quality and perceived switching cost positively and significantly influence intentions to Leapfrog. However, the urgency to replace does not influence choices to leapfrog.

Originality/value: The study findings bring a new understanding of the determinants of consumer leapfrogging and their intentions to leapfrog in the mobile phone industry and highlight the role perceived product quality and switching cost play in determining intention leapfrog. 


\section{Introduction}

The concept of Leapfrogging has raised a great interest in the minds of both scholars and practitioners in recent times. Businesses face challenges because of the ever-changing consumer buying behavior in terms of taste and preferences because of the choices available to them in the market. Because of these changes, consumers decide to delay buying existing products and wait to buy more modified or improved product generation in the future (Herrmann et al., 2017).

This phenomenon, known in the literature as leapfrogging, happens when companies, end-users, or nations decide to embrace innovation while forgoing the established one in expectation of the upcoming product (Binz et al., 2012; Cripps \& Meyer, 1994; Holak \& Lehmann, 1990). This has created interest to scholars and practitioners as they seek to explore how, when, and why consumers skip existing technologies and wait for newer generations. However, minimal literature on the subject and what exists is not based on any theoretical frameworks. Thus, creating an opportunity for further investigation into this phenomenon.

This is affirmed by Herrmann et al. (2017), who assert that some of these variables and their impact on leapfrogging have been studied but in isolation, thus, indicating a lack of a comprehensive analysis of their effect on leapfrogging. Furthermore, Herrmann et al. (2017) argue that prior research falls short of a significant examination of the interrelationship between end-user attributes and perceived quality of various product generations in determining leapfrogging. Given these shortcomings, it is critical to conduct a more thorough examination of the predictors leading to consumer leapfrogging intention by combining these elements into a single conceptual model, which is the focus of the current study.

In developed countries, customers usually embrace innovation by replacing the original device with the new and improved one. In the decision-making process, customers are likely to equate the old with the new model and balance the advantages of upgrading against switching costs, e.g., compatibility, learning, and sunk costs. In developing countries, however, consumers may purchase a smartphone as their first mobile device because they do not have a basis for comparison, so their decision-making process would be different. Consumers in these markets should find it easier to learn about new radical technologies because they do not have a static cognitive structure to override.

The mobile phone handset has gained global acceptance in a relatively short period (Barnes \& Scornavacca, 2004). Today, this device is indispensable in the lives of the vast majority of consumers, particularly young teenagers. It is a device that many customers can't seem to live without; they always have it on and carry it with them almost wherever they go. For these customers, the mobile device is essential for staying in touch with acquaintances, family and, as a result, demonstrate their identity and uniqueness (Grant \& O'Donohoe, 2007; Sultan \& Rohm, 2005). For marketing professionals, the increased use of digital devices provides a vast business opportunity to connect with customers and serve them whenever and wherever they want (Barutçu, 2007; Grant \& O'Donohoe,2007; Roach, 2009). Furthermore, the widespread presence of these mobile phone brands has a significant impact on the customer's daily life and customer journey when using or embracing them.

Despite recent interest in this topic, little has been identified about consumers' choice processes in developing countries when dealing with new technologies. Thus, this research aims to bridge that gap by evaluating the determinants of leapfrogging intention and how these affect the adoption of the various mobile phone technologies available in Kenya at each point of the customer selection process. 


\section{Literature Review}

\section{Theory of Planned Behavior (TPB)}

This theory is a development of reasoned action (TRA) theory, which was created to address the limitations of the TRA (Ajzen \& Fishbein, 1975; Fishbein \& Ajzen, 1980). The theory of planned behavior assumes that individuals' behavioral intention and actual behavior are influenced by their attitude toward behavior, normative beliefs, and behavioral control (Ajzen, 1991). This theory guides the current study on the premise that the individual's likelihood or willingness to perform an act depends on the person's attitude towards the behavioral outcome (Ajzen, 1991), in which case intention to leapfrog and perceived behavioral control factors facilitates or impedes the performance of the behavior. Factors used in this study to influence intentions to leapfrog include perceived product quality, perceived switching cost, and urgency to replace.

Theory of planned behavior has been applied to various studies in varied sectors to review consumer behavior like e-coupon usage (Oh et al., 2006), green consumption (Sparks \& Shepherd, 1992), smoking intention (Godin et al., 1992), e-commerce services (Bhattacherjee, 2000; Tonglet et al., 2004). Since this is a behavioral study, we believe that the theory is relevant in influencing the intentions of leapfrogging.

\section{Schumpeterian Growth Theory}

Schumpeterian Growth Theory is the branch of innovation-based growth theory developed by Aghion \& Howitt (1992). According to the World Bank Group and China Development Bank (2017), this theory emphasizes quality-improving innovations that prevent the need for older products. It thus involves the thrust that Schumpeter so aptly dubbed "creative destruction." The Schumpeterian model's first implication is that faster growth generally implies a higher rate of firm turnover because creative destruction generates the entry of new innovators and the exit of former innovators.

The majority of research on consumer adoption of new products has concentrated on the psychological barriers to adoption and the level of consumption or diffusion models. For instance, decision-making scholars have developed decision-making frameworks to explain the mental process of adopting an innovation (Boyd \& Mason, 1999; Clark \& Staunton, 1989; Turnbull \& Meenaghan, 1980). In particular, scholars have focused their attention on understanding the barriers to adopting technological breakthroughs, also known as radical innovations (Wheelwright \& Clark, 1992). It has been discovered that the procedure, timeframe, and outcome of adoption and implementation, especially for the next products, are dependent on product-specific and adopter-specific factors, including the device's performance expectancy, functionality, complexity, serviceability, and testability (Rogers, 1995).

In addition, there is vast literature examining the rate of diffusion of new products in different markets. The findings demonstrate the importance of relevant social and cultural conditions in developing and using emerging innovations (Herbig \& Dunphy, 1998). According to Steinmueller (2001), leapfrogging's diffusion is hampered by the degree of technology adaptation to local needs, the costs, knowledge, and skills required for effective adoption, and market dynamics. These challenges exacerbate in developing nations, hence hindering the speed of diffusion in developing countries.

\section{Determinants of leapfrogging intention}

Although there is a large body of literature on how people perceive and adopt radical technologies and how quickly new products spread across a population, only a few studies have looked at consumers' decisions to postpone purchasing a new generation product to a later date. For example, Herbig and Dunphy (1998) examined the drivers of consumer leapfrogging in the automotive industry in the United States found that perceived urgency, quality of the new product, perceived condition, switching costs determine the occurrence 
of intention to leapfrog. This research also showed that cost of switching was by far the most important predictor. Additionally, their findings show that the relationship between leapfrogging intention and leapfrogging behavior was stronger as consumers' income increased. Unfortunately, no theoretical framework was proposed to explain the results.

According to other studies, the decision to upgrade is influenced by consumers' expectations of future price levels, product attributes, and availability of the product (Song \& Chintagunta, 2003). In addition, diffusion studies suggest that consumers' purchase history determines the decision to adopt a newer version of a product, expectations about the recent generation performance, and preferences for the current generation (Bardhan \& Chanda, 2008). Furthermore, replacement intentions are related to the perceived condition of the existing product (Bayus \& Gupta, 1992). The studies mentioned earlier shed some light on factors associated with consumer intention to leapfrogging in developed countries. Unfortunately, previous studies are limited in that they do not propose a theoretical mechanism for the findings. The sample of countries investigated hinders the generalizations of the results into developing nations. The current study adopts perceived product quality, perceived switching cost, and urgency to replace as determinants of intention to leapfrog in a developing country setting.

Therefore, the research questions guiding the study include

RQ1.Does perceived product quality determine intention to leapfrog in a developing nation setting?

RQ2. Does perceived switching cost establish an intention to leapfrog in a developing nation setting?

RQ3. Will urgency to replace determine the intention to leapfrog in a developing nation setting?

\section{Perceived product quality and intention to leapfrog}

Product quality is an important consideration when determining purchase intent and leapfrogging intentions. It is an ongoing process of improving product attributes to improve the overall performance and, as a result, customer satisfaction. To keep up with changing customer tastes and preferences, quality should be improved at all times (Mirabi et al., 2015). Moreover, quality is an essential tool for creating a competitive advantage (Zeeshan \& Obaid, 2013). Chi et al. (2008) and Madahi and Sukati (2012) states that customers purchasing intention depends on product quality. Therefore, it is assumed in this study that the perceived product quality will lead to a delay or postponement of the purchase of the current product on the market as consumers wait for the next generation of the product to be perceived as having better satisfaction or performance.

According to Desai et al. (2014), the potential customers seem to be more quality-oriented when purchasing cosmetics since they wait for the product during non-availability. It has been observed that if a product meets the customer's expectations, the consumer is satisfied and considers the item to be satisfactory or even outstanding (Alhedhaif et al., 2016). If the consumer's requirements are not met, they will conclude that the product is of poor quality. As a result, (Wright et al., 2006) describes product quality as the attributes and features of a product or service that significantly impact the ability to fulfill the needs and desires of customers.

According to research, customers' expectations of future brand generations have an impact on intent to leapfrogging (Kim et al., 2001; Song \& Chintagunta, 2003). Aside from material changes, the existing brand (P0) is susceptible to presumed depreciation due to the simple appearance of a better replacement that may come to the market (P1). Such viewed deterioration may also be linked to the perception that the previous brand is no longer cutting-edge in terms of features or attributes. Users may perceive the true extinction of the old brand if the particular entrant brand has excellent features and performance. 
For instance, the previous brand may no longer reflect the most recent technological advancement, while the new model performs its work more efficiently, faster, and more simply. As a result, the users' expectations for different product developments are directly or indirectly influenced by mental and emotional decrepitude (Antioco \& Kleijnen, 2010; Holak \& Lehmann, 1990; Levinthal \& Purohit, 1989). For customers to try the new entrant brand (P1) as a substitute for the old-fashioned one (P0), those above must be an enhancement (even if only viewed as such by customers) then the latter. The intention to focus or turn to new brands increases with the assumption that they will offer greater quality advantages in terms of performance compared to the old ones on the market (Boone, 2001; Druehl et al., 2009). Consumers will be less interested in leapfrogging to P2 if enhancements in P1 (especially in comparison to P0) surpass a certain threshold. The decision to adopt the presently offered brand provides significant value for the customers over the older model. Based on the above discussion, we hypothesize that:

\section{H1: Perceived product quality positively and significant influences intention to leapfrog}

\section{Perceived Switching cost and intention to leapfrog}

When customers think of changing whatever product they want to, the cost incurred in changing it is paramount. Switching costs are described as the risks, investments, and losses that consumers must bear as a response to changing their cell devices or brands to new ones. Some prior studies have indicated that the cost of switching from one product to the other can be divided into four categories: financial, time, psychology, and associations (Whitten \& Wakefield, 2006). Switching costs are a constraint to scrutinizing future product providers (Wathne et al., 2001)) to the level that even when people or firms recognize costs or exit barriers, they tend to stick with their current supplier (Burnham et al., 2003; Quoquab et al., 2018). Dissatisfaction with the service quality, price, or firm will motivate the intention to switch suppliers if switching costs are low. If they are too high, many dissatisfied customers are likely to exhibit false loyalty.

Studies have reported that switching costs can act as a moderating variable, negatively affecting the relationships between satisfaction and intention to keep the relationship (Burnham et al., 2003; Oliva et al., 1992; Sharma \& Patterson, 2000). The effect of satisfaction on sustaining the connection decreases as costs rise, and vice versa. Kim et al. (2004) investigated switching costs in the context of mobile phone service, viewing them as a combination of loss cost, adaptation cost, and move-in cost. According to the authors, loss cost refers to the consumers' perception of losing social standing, relationships, and productivity when switching to the established service provider. In contrast, adjustment cost refers to the difficulties associated with introducing a particular service provider after switching to the current one.

This article examines switching costs in the context of mobile phone usage as the one-time costs that mobile phone users incur when shifting from one mobile generation to another. This cost is the sum of the loss cost, the adjustment cost, and the shift cost (Burnham et al., 2003; Kim et al., 2004).

As per the cost frameworks in buying behavior, customers evaluate the adjustment in net benefit (Quoquab et al., 2018). When shifting to another anticipated brand, if the switching costs are greater than the increase in usefulness, people will prefer not to shift. Thus, switching costs significantly impact or predict customer loyalty and disloyalty behavior (Kim et al., 2004). Hence, we hypothesize that:

\section{H2: Switching cost positively and significantly affects intention to leapfrog}

\section{The urgency to replace and intention to leapfrog.}

Another determinant of leapfrogging considered in this study was an urgency to replace the product. Users who intend to purchase anticipated new product devices must bridge the gap between that product and the currently 
owned product $(\mathrm{P} 0)$. Customers who own a product are expected to differ in their perceived urgency of changing the existing item, and a variety of factors will inspire this urgency.

When deciding whether to forego the new product (P1) but instead wait for the anticipated brand, the consistency in quality of the old brand is an important issue (P2). The user's desire to buy the latest brand is highly influenced by the functionality of the existing offering (Evans et al., 1989; Rogers, 1995). The functionality of any product degrades over time due to wear and tear, and with the advancement of technology, increased breakdowns of most items are to be anticipated. Bayus \& Gupta (1992) have shown that the customer's perceptions of the currently owned brand influences motivations to substitute it with a new or the anticipated one (Labay \& Kinnear, 1981).

Furthermore, buyers' aspiration for variety and change significantly affects the urgency with which the existing brand (P0) must be replaced by the anticipated brand (P1 or P2). Such desire stimulation by a new device has proven to be an important aspect of purchasing behavior (Wang et al., 2008)). Furthermore, the arrival of a new development process causes the extinction of the preceding version, decreasing the value and performance of the current item in the client's mind. The haunting of a decrease in value can inspire an intention of replacing the old product.

The necessity to substitute is an essential element of retailer-brand partnerships because it allows retailers to monitor customers' strategic behavior. In other words, because retailers sell a wide variety of sales items continuously, buyers prefer to wait until the retailer offers a special offer before deciding to buy (Levy \& Goldberg, 2014). Regrettably, this is especially true for clothing items with a limited sales season. Nevertheless, scarcity of resources can strain end-users (Herrington \& Capella, 1995). In other words, retailers that sell limited edition items can create a sense of novelty and scarcity, which may dissuade buyers from postponing their purchasing decision even after agreeing to pay in full. This is among the effective strategies employed by most fashion companies (Jin et al., 2012). As a result, we can opine that consumers' increased motivation to substitute is the main factor in cultivating increased revenues for retail outlets. We therefore propose:

\section{H3: Urgency to replace positive and significantly affect intention to leapfrog}

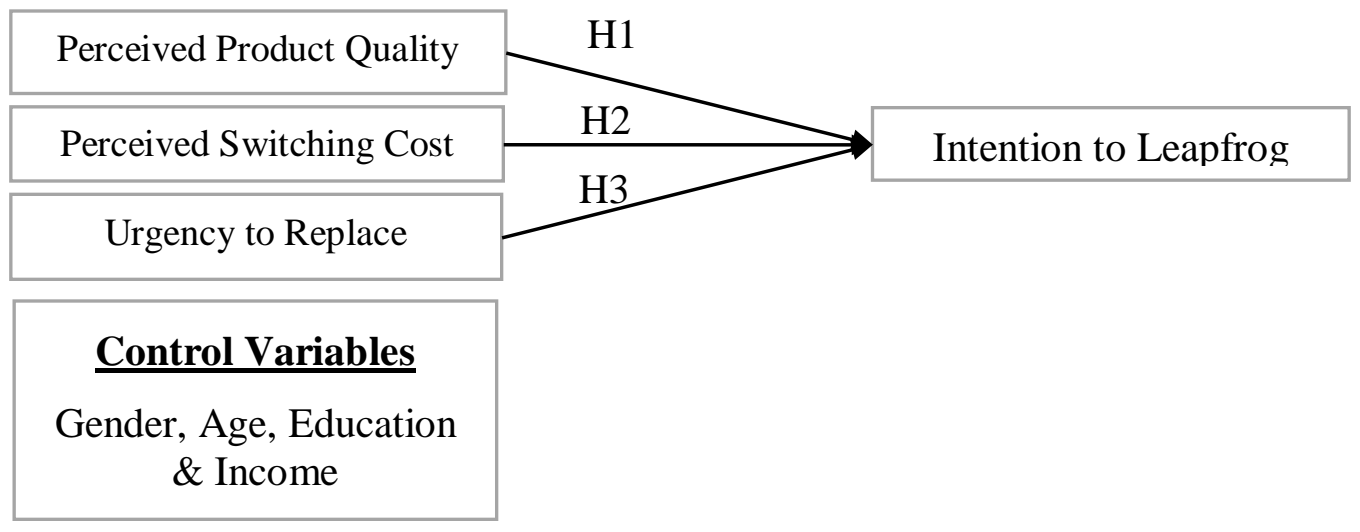

Figure 1: Conceptual Framework

\section{Methodology}

\section{Design and participants}

The research paper employs a cross-sectional survey design, stratified and simple random sampling techniques, and a structured closed-ended questionnaire to collect data from a population of interest of 15506 employees 
of three Cosmopolitan County Governments of Trans-Nzoia, Nakuru, and Nairobi. Fisher et al.,(1983)'s formula was used to get the sample size of 384. A total of 384 survey instruments were distributed, with 349 completed and returned, representing a response rate of $90.89 \%$. Since the response rate was greater than $75 \%$, it was deemed adequate and representative of the population (Nyanjom, 2013).

Respondents' profile shows that most of the respondents were male with $59.7 \%(\mathrm{n}=206)$, while females were $40.3 \%(\mathrm{n}=139)$. Results relating to age revealed that the majority $(55.4 \%, \mathrm{n}=191)$ were between ages 29 and 39 years, while those above 50 were the least $(5.5 \%, n=9)$. Furthermore, the study indicates that the majority of the respondents $(58 \%, n=200)$ had a bachelor's degree while the least $(1.4 \%, n=5)$ had a high school certificate. Finally, results of respondents' income show that $62.5 \%(n=218)$ earns above 50,000 while those earning below 50,000 were $37.5 \%(n=131)$

\section{Measurement}

All items used to measure the study variables in the current study were adapted from previous studies with only minor changes. Intention to leapfrog measurements was adopted from Venkatesh and Davis (2000) and modified to suit the current study. The items include; "I will wait until the next mobile phone generation is available," "I will wait provided that announcements about the next generation mobile phones are already available," "I will recommend other customers to wait until a future model is released."

Five items adopted from Herrmann et al. (2017) were used to measure perceived product quality. "My Mobile phone has good security features than what is available currently," "I like the design of my Mobile phone," "I enjoy using my phone," "I like the features in my phone," and "My mobile phone is environmentally friendly."

Perceived switching cost had five items also adopted from Herrmann et al., (2017). The items include, "Learning to use a new mobile phone will take a long time," "It will take a lot of effort to learn to use a new mobile phone," "the price of the current phone is high," "My phone will lose value with the introduction of a new phone," "It will be costly to repair my old phone before I switch to the new phone."

The urgency to replace had six items also adopted from Herrmann et al. (2017) and modified. The items include, "I like to change things in my life," "I like variety in my life," "I am not satisfied with my old phone," "I like things of good value," "I like things that make my work easy," "when there is a need to replace my phone, I will do a replacement purchase."

\section{Results}

\section{Descriptive Statistics}

The descriptive statistics of the study variables are shown in Table 1. Findings show that perceived product quality and urgency to replace had the highest mean of 5.4 and SD $=1.188,1.239$, respectively. This was followed by intentions to leapfrog with a mean of 4.5 and $\mathrm{SD}=1.231$, and finally, switching cost had the least mean of 4.0 with $\mathrm{SD}=1.329$. Additionally, the Table shows the reliability test results with Cronbach's Alpha values being at the acceptable level above .6 apart from switching cost, which had a scale of .570. Finally, correlation analysis shows that the relationship between intentions to leapfrog and perceived product quality has the strongest relationship as demonstrated by $\mathrm{r}=.563, \mathrm{p}<.01$, as perceived switching cost, $\mathrm{r}=.246, \mathrm{p}<.01$, and urgency to replace, $\mathrm{r}=.272, \mathrm{p}<.01$ indicating the least but significant association with intentions to leapfrog respectively. 
Table 1: Descriptive, Reliability and Cronbach's Analysis

\begin{tabular}{lccccccc}
\hline Variable & Mean & SD & $\boldsymbol{\alpha}$ & \multicolumn{5}{c}{ Correlation } \\
& & & & & & \\
\hline Intentions to Leapfrog & 4.5 & 1.231 & .604 & 1 & & \\
Perceived product Quality & 5.4 & 1.188 & .720 & $.563^{* *}$ & 1 & \\
Perceived switching cost & 4.0 & 1.329 & .570 & $.246^{* *}$ & $.228^{* *}$ & 1 \\
Urgency to Replace & 5.4 & 1.239 & .620 & $.152^{* *}$ & $.133^{*}$ & $.207^{* *}$ & 1 \\
\hline ** Correlation is significant at the 0.01 level, * implies that correlation is significant at the 0.05 level (2-tailed).
\end{tabular}

\section{Validity Test of the instrument}

Factor analysis was used to check for construct validity before testing the study hypotheses. Table 2 shows how each item was factored utilizing principal component analysis and Varimax rotation. The Table shows how the items loaded into four variables accounted for $62.7 \%$ of the variance, with product quality having 3 items loading under component 1 with two of its items dropped from the study because they did not meet the criteria of loading above 0.5. Findings show that this variable indicates an Eigenvalue of 2.357, explaining $19.65 \%$ of the variance. All the 3 items measuring intentions to leapfrog were all loaded on component 2 . This component had an Eigenvalue of 2.126, with these items explaining $17.72 \%$ of the total variance. In addition, results show that 3 items measuring urgency to replace loaded on component 3 . This component shows an Eigenvalue of 1.724 , with items accounting for $14.36 \%$ of the variance. Three items of this variable were removed as they did load. Finally, three items measuring perceived switching cost loaded on component 3 with two items dropped from the study. The factor indicates an Eigenvalue of 1.315 with the items explaining a total of $10.96 \%$ variance. The Table shows the Kaiser-Meyer-Olkin Measure of sampling adequacy (KMO) of .524. Bartlett's Test of Sphericity shows a Chi-Square of 1066.749 with $\mathrm{df}=66$ significant $\mathrm{p}=.000$, which confirmed the suitability of factor analysis.

Table 2: Factor Analysis

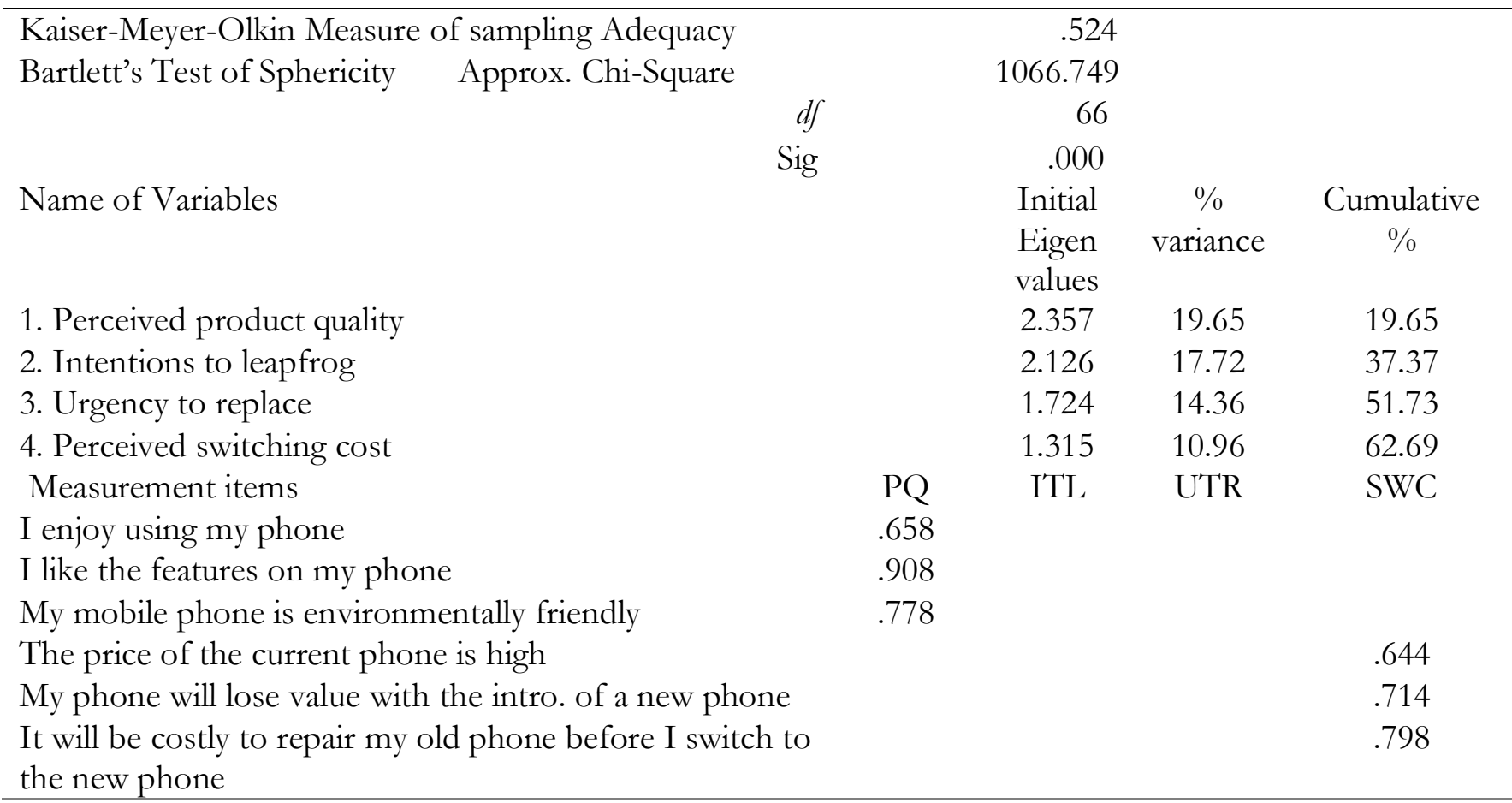


I like to change things in my life

I am not satisfied with my old phone

I like things of good value

I will wait until the next Mobile phone generation is available.

I will wait if announcements about the next generation

Mobile phones are already available

I will recommend other customers to wait until a future model is released
.694

.638

.835
.780

.782

.547

Note: PQ-Perceived Product Quality, ITL- Intentions to Leapfrog, UTR-Urgency to Replace, SWC- Switching Cost

\section{Hypotheses Testing}

Table 3 reveals the results of the study. Findings in Model 1 shows results of the control variables. Results indicate that age $(\beta=-.474, \mathrm{p}=.000)$ and respondents income age $(\beta=.177, \mathrm{p}=.028)$ all had a significant influence on intentions to leapfrog as gender $(\beta=-.074, \mathrm{p}=.587)$ and education $(\beta=-.061, \mathrm{p}=.127)$ were insignificant. This model accounts for $7.5 \%$ of the variance in intentions to leapfrog as indicated by $\mathrm{R}^{2} .075, \mathrm{~F}=$ $6.923, \mathrm{p}=.000$.

Model 2 of the same Table 3 shows H1, H2, and H3 while holding constant the control variables. The study findings of the controls indicate that only age $(\beta=-.264, \mathrm{p}=.001)$ was discovered to have a significant impact on leapfrogging intentions as respondents' gender, income and education were all insignificant as indicated with $\mathrm{p}>.05$. This model explains $36.1 \%$ of the variance as shown by $\mathrm{R}^{2} .361, \Delta \mathrm{R}^{2} .287, \mathrm{~F}=51.038, \mathrm{p}=.000$. The change in $\mathrm{R}^{2} .287$ indicates that while holding constant the control variables in the study, independent variables (perceived product quality, perceived switching cost, and urgency to replace) explain a $28.7 \%$ variance in intentions to replace. Findings further reveal that perceived product quality $(\beta=.529, \mathrm{p}=.000)$ and perceived switching cost $(\beta=.092, \mathrm{p}=.030)$ positively influence intentions to leapfrog. Based on these findings, H1 and $\mathrm{H} 2$ are both supported by the study. However, urgency to replace $(\beta=.072, \mathrm{p}=.109)$ was discovered to have an insignificant impact on leapfrogging intentions. Hence $\mathrm{H} 3$ is not supported by the study.

Table 3: Regression Findings

\begin{tabular}{|c|c|c|c|c|}
\hline Variable & Model 1 & & Model 2 & \\
\hline & $\beta$ & $p-v$ & $\beta$ & $p-v$ \\
\hline Constant & $5.542 * * *$ & .000 & $1.060 *$ & .030 \\
\hline Gender & -.074 & .587 & .067 & .558 \\
\hline Age & $-.474 * * *$ & .000 & $-.264 * * *$ & .001 \\
\hline Income & $.177 *$ & .028 & .106 & .117 \\
\hline Education & -.161 & .127 & .028 & .756 \\
\hline Product Quality & - & - & $.529 * * *$ & .000 \\
\hline Switching Cost & - & - & $.092 *$ & .030 \\
\hline Urgency to Replace & - & - & .072 & .109 \\
\hline $\mathrm{R}^{2}$ & \multicolumn{2}{|c|}{.075} & \multicolumn{2}{|c|}{.361} \\
\hline$\Delta \mathrm{R}^{2}$ & \multicolumn{2}{|c|}{.075} & \multicolumn{2}{|c|}{.287} \\
\hline $\mathrm{F}$ & \multicolumn{2}{|c|}{$6.923 * * *$} & \multicolumn{2}{|c|}{$51.038^{* * *}$} \\
\hline
\end{tabular}

Note: ${ }^{*} p<.05, * * * p<.001$, Dependent Variable $=$ Intention to leapfrog 


\section{Discussion}

The results on perceived product quality and intentions to leapfrog indicate that consistency in product quality is a critical factor in evaluating leapfrog intentions. This suggests that if a product is of higher quality, consumers will be more likely to get it however long it may take to be released on the market (Chi et al., 2008). These findings support the claim put forward in the work of Herrmann et al. (2017) that Consumers may postpone upgrading to a newly developed (currently available on the market) product on the market (P1) until a later date when an even newer version is released (P2) perceived to be of a better, updated or enhanced version of goods that will be available in the near future. However, the author's findings indicate that product quality is a less influential factor when it comes to leapfrogging.

Our study results support the argument of Desai et al. (2014), who says that when it comes to cosmetic products, consumers are found to be more quality conscious because they patiently await the brand during non-availability instead of purchasing what exists on the market at the time of their need. Thus, if consumers anticipate that future product generations of phones will have better and additional features, like high operation speed, or faster internet connections, they may be influenced to leapfrog.

Results of switching costs influence on intentions to leapfrog is also supported in the current study. The cost of switching refers to the risk, investment, and loss that consumers may incur due to shifting suppliers or established products. Consumers must pay close attention to the costs related to switching product generations (Bardhan \& Chanda, 2008). Our findings support the above statement as it reveals that switching costs influence consumers' intentions to leapfrog. This supports the study by Herrmann et al. (2017), whose analysis indicates that the propensity to leapfrog is primarily dictated by the projected costs of transitioning from the existing brand (P0) to the emerging of a new entrant (P1). About the current study, this implies that if consumers anticipate that the cost of replacing the presently offered cell device on the market will be high, their propensity to buy what is currently available will be lower. At the same time, their tendency to wait for the future phone (brand) would be significantly greater (Levinthal \& Purohit, 1989). Our findings are also consistent with Kim et al. (2004), who claim to switch costs play a significant role in determining consumer retention and changing behavior.

Finally, our study results reveal that urgency to replace insignificantly affects the intention to leapfrog. This suggests that customers will be willing to purchase the latest cell phone available on the market when there is an immediate need to replace it, implying that customers will not be waiting for the future phone to be made available when they urgently need to replace it what they have. This supports Gupta (2013), who states that the desire of a buyer to substitute an existing product as soon as possible is referred to as urgency to replace. The consumer's desire for variety and change influence the urgency with which the existing product must be replaced with the anticipated one. Such activation of the needs of a new product has proven to be the core determinant of purchasing behavior. The consumer, who is influenced by the current product's functionality, will be compelled by the desire of urgency of purchasing a new product (Evans et al., 1989; Rogers, 1995). As a result, the presumed status of the currently owned item influences behavioral intention to substitute it (Labay \& Kinnear, 1981).

\section{The Study's Implications for Theory and Practice}

The current study findings have significant implications for theory and previous research. First, the study findings support the existing minimal literature that perceived product quality and switching cost influences consumers' intentions to leapfrog. Secondly, the study supports the theory of planned behavior, which contends that a person's behavioral intention is determined by their attitude, normative beliefs, and control beliefs. When a consumer perceives that the next generation product would perform better than what is on the market, the intention to leapfrog increases leading to skipping what is already available; this action can be shaped by a 
myriad of factors, including product features, perceived quality, and perception of the production nation (Wang et al., 2008). Finally, the study backs up Schumpeterian Growth Theory, which relies heavily on quality and performance improving features that make old brands outdated, which is the current study's focus. In this case, customers will forego what is currently available in the belief that the next generation brand will be far high in performance compared to what is presently available on the market.

Managers need to realize that consumers expect new generation products to have better safety, higher quality features, better performance than is currently available. Therefore, these features should be integrated into the new product for higher acceptability during the product development period. In addition, the anticipated new version of products should have features that require less effort and time for consumers to learn how to use them, for this has been found to influence leapfrog intentions. Finally, policy decisions should indeed be set up to ensure that service providers invest enough time and effort in broadening their knowledge and understanding of the variables that determine the adoption of new technology and continued use of technological innovations, as these factors contribute to leapfrogging intentions.

\section{Limitations of the study}

This study used a particular generation of the product, a cell phone, to analyze the intention to leap, which inevitably restricts our implications. Factors such as the length of the lifespan, the replacement cost, and the valuation of the derelict product are likely to trigger the importance of consumer predictors to vary. Further research is needed to provide a definitive answer on how to generalize the study's findings, particularly with a broad range of product categories that vary widely from mobile phones regarding the various characteristics and user information that represent multiple generations of each product line.

Second, because data were collected at a single point in time, the current study was cross-sectional. A longitudinal study would be recommended because it could provide additional information. Finally, the study used quantitative data, integrating a mixed approach into future research, is recommended as it may reveal other leapfrogging determinants that the present paper has not captured.

\section{Conclusion}

Based on the findings of the study, we can conclude that the higher the customer perception of the new product as a functional improvement over the older one, the greater the likelihood for the customers to leapfrog. Thus, Mobile phone manufacturers can utilize such a chance to create phones that reflect the most recent technology, with better features and performance, faster in speed, simpler, and more enjoyable to use. The study also discovered that the costs of switching from an existing product to the new one have a significant impact on leapfrogging intentions. As a result, both monetary and non-monetary investments, such as time and effort spent learning how to use the new mobile phone, should be considered while creating awareness of the future phones as these could influence customers' intention to leapfrog.

Funding: No external funding was received by the authors

Conflicts of Interest: Authors have no conflict of interest.

\section{References}

Aghion, P., \& Howitt, P. (1992). A Model of Growth Through Creative Destruction. Econometrica, 60(2), 323351. doi: $10.2307 / 2951599$

Ajzen, I. (1991). The theory of planned behavior. Organizational behavior and human decision processes, 50(2), 179211.

Ajzen, I., \& Fishbein, M. (1975). A Bayesian analysis of attribution processes. Psychological bulletin, 82(2), 261. 
Alhedhaif, S., Lele, U., \& Kaifi, B. A. (2016). Brand loyalty and factors affecting cosmetics buying behavior of saudi female consumers. Journal of Business Studies Quarterly, 7(3), 24.

Antioco, M., \& Kleijnen, M. (2010). Consumer adoption of technological innovations. European Journal of Marketing.

Bardhan, A., \& Chanda, U. (2008). A model for first and substitution adoption of successive generations of a product. International Journal of Modelling and Simulation, 28(4), 487-494.

Barnes, S. J., \& Scornavacca, E. (2004). Mobile marketing: the role of permission and acceptance. International Journal of Mobile Communications, 2(2), 128-139.

Barutçu, S. (2007). Attitudes towards mobile marketing tools: A study of Turkish consumers. Journal of Targeting, Measurement and Analysis for Marketing, 16(1), 26-38.

Bayus, B. L., \& Gupta, S. (1992). An empirical analysis of consumer durable replacement intentions. International Journal of Research in Marketing, 9(3), 257-267.

Bhattacherjee, A. (2000). Acceptance of e-commerce services: the case of electronic brokerages. IEEE Transactions on systems, man, and cybernetics-Part A: Systems and humans, 30(4), 411-420.

Binz, C., Truffer, B., Li, L., Shi, Y., \& Lu, Y. (2012). Conceptualizing leapfrogging with spatially coupled innovation systems: The case of onsite wastewater treatment in China. Technological Forecasting and Social Change, 79(1), 155-171.

Boone, J. (2001). Intensity of competition and the incentive to innovate. International Journal of Industrial Organization, 19(5), 705-726.

Boyd, T. C., \& Mason, C. H. (1999). The link between attractiveness of "extrabrand" attributes and the adoption of innovations. Journal of the Academy of Marketing Science, 27(3), 306-319.

Burnham, T. A., Frels, J. K., \& Mahajan, V. (2003). Consumer switching costs: a typology, antecedents, and consequences. Journal of the Academy of Marketing Science, 31(2), 109-126.

Chi, C.-F., Lee, Y.-L., \& Weng, H.-S. (2008). A CdS-modified TiO2 nanocrystalline photoanode for efficient hydrogen generation by visible light. Nanotechnology, 19(12), 125704.

Clark, P., \& Staunton, N. (1989). Innovation in technology and organization.

Cripps, J. D., \& Meyer, R. J. (1994). Heuristics and biases in timing the replacement of durable products. Journal of Consumer Research, 21(2), 304-318.

Desai, M. M., De Abreu, A. L. C., Goh, A. C., Fairey, A., Berger, A., Leslie, S., . . Aron, M. (2014). Robotic intracorporeal urinary diversion: technical details to improve time efficiency. Journal of endourology, 28(11), 1320-1327.

Druehl, C. T., Schmidt, G. M., \& Souza, G. C. (2009). The optimal pace of product updates. European Journal of Operational Research, 192(2), 621-633.

Evans, D. J., McKeating, J., Meredith, J. M., Burke, K. L., Katrak, K., John, A., . . Almond, J. W. (1989). An engineered poliovirus chimaera elicits broadly reactive HIV-1 neutralizing antibodies. Nature, 339(6223), 385-388.

Fishbein, M., \& Ajzen, I. (1980). Predicting and understanding consumer behavior: Attitude-behavior correspondence. Understanding attitudes and predicting social behavior, 148-172.

Fisher, W. A., Byrne, D., \& White, L. A. (1983). Emotional barriers to contraception. Adolescents, sex, and contraception, 207-239.

Godin, G., Valois, P., Lepage, L., \& Desharnais, R. (1992). Predictors of smoking behaviour: an application of Ajzen's theory of planned behaviour. British journal of addiction, 87(9), 1335-1343.

Grant, I., \& O’Donohoe, S. (2007). Why young consumers are not open to mobile marketing communication. International journal of advertising, 26(2), 223-246.

Group, W. B., \& Bank, C. D. (2017). Leapfrogging: The Key to Africa's Development? : World Bank.

Gupta, S. (2013). The psychological effects of perceived scarcity on consumers' buying behavior.

Herbig, P., \& Dunphy, S. (1998). Culture and innovation. Cross Cultural Management, 5(4), 13-21. 
Herrington, J. D., \& Capella, L. M. (1995). Shopper reactions to perceived time pressure. International Journal of Retail \& Distribution Management.

Herrmann, A., Sprott, D., \& Schlager, T. (2017). What drives leapfrogging? empirical assessment of consumer determinants of leapfrogging. Total Quality Management \& Business Excellence, 28(3-4), 266-281.

Holak, S. L., \& Lehmann, D. R. (1990). Purchase intentions and the dimensions of innovation: An exploratory model. Journal of Product Innovation Management: an international publication of the product development \& management association, 7(1), 59-73.

Jin, B., Jung, H., Matthews, D. R., \& Gupta, M. (2012). Fast fashion business model: what, why and how? Fashion supply chain management: Industry and business analysis (pp. 193-211): IGI Global.

Kim, M.-K., Park, M.-C., \& Jeong, D.-H. (2004). The effects of customer satisfaction and switching barrier on customer loyalty in Korean mobile telecommunication services. Telecommunications policy, 28(2), 145-159.

Kim, N., Srivastava, R. K., \& Han, J. K. (2001). Consumer decision-making in a multi-generational choice set context. Journal of Business Research, 53(3), 123-136.

Labay, D. G., \& Kinnear, T. C. (1981). Exploring the consumer decision process in the adoption of solar energy systems. Journal of Consumer Research, 8(3), 271-278.

Levinthal, D. A., \& Purohit, D. (1989). Durable goods and product obsolescence. Marketing Science, 8(1), 35-56.

Levy, O., \& Goldberg, Y. (2014). Dependency-based word embeddings. Paper presented at the Proceedings of the 52nd Annual Meeting of the Association for Computational Linguistics (Volume 2: Short Papers).

Madahi, A., \& Sukati, I. (2012). The effect of external factors on purchase intention amongst young generation in Malaysia. International Business Research, 5(8), 153.

Mirabi, V., Akbariyeh, H., \& Tahmasebifard, H. (2015). A study of factors affecting on customers purchase intention. Journal of Multidisciplinary Engineering Science and Technology (JMEST), 2(1).

Nyanjom, C. R. (2013). Factors influencing employee retention in the state corporations in Kenya. University of Nairobi.

Oh, J., Park, J. H., Lim, Y., Lim, H., Oh, Y., Kim, J. S., . . Lim, D. (2006). Full integration of highly manufacturable $512 M b$ PRAM based on 90nm technology. Paper presented at the 2006 International Electron Devices Meeting.

Oliva, T. A., Oliver, R. L., \& MacMillan, I. C. (1992). A catastrophe model for developing service satisfaction strategies. Journal of Marketing, 56(3), 83-95.

Quoquab, F., Mohammad, J., Yasin, N. M., \& Abdullah, N. L. (2018). Antecedents of switching intention in the mobile telecommunications industry. Asia Pacific Journal of Marketing and Logistics.

Roach, G. (2009). Consumer perceptions of mobile phone marketing: a direct marketing innovation. Direct marketing: an international journal.

Rogers, E. M. (1995). Diffusion of Innovations: modifications of a model for telecommunications Die diffusion von innovationen in der telekommunikation (pp. 25-38): Springer.

Sharma, N., \& Patterson, P. G. (2000). Switching costs, alternative attractiveness and experience as moderators of relationship commitment in professional, consumer services. International journal of service industry management.

Song, I., \& Chintagunta, P. K. (2003). A micromodel of new product adoption with heterogeneous and forwardlooking consumers: Application to the digital camera category. Quantitative Marketing and Economics, 1(4), 371-407.

Sparks, P., \& Shepherd, R. (1992). Self-identity and the theory of planned behavior: Assesing the role of identification with" green consumerism". Social psychology quarterly, 388-399.

Steinmueller, W. E. (2001). ICTs and the possibilities for leapfrogging by developing countries. Int'l Lab. Rev., 140, 193.

Sultan, F., \& Rohm, A. (2005). The coming era of" brand in the hand" marketing. MIT Sloan Management Review, $47(1), 83$. 
Tonglet, M., Phillips, P. S., \& Read, A. D. (2004). Using the Theory of Planned Behaviour to investigate the determinants of recycling behaviour: a case study from Brixworth, UK. Resources, conservation and recycling, 41(3), 191-214.

Turnbull, P. W., \& Meenaghan, A. (1980). Diffusion of innovation and opinion leadership. European Journal of Marketing.

Venkatesh, V., \& Davis, F. D. (2000). A theoretical extension of the technology acceptance model: Four longitudinal field studies. Management science, 46(2), 186-204.

Wang, G., Dou, W., \& Zhou, N. (2008). Consumption attitudes and adoption of new consumer products: a contingency approach. European Journal of Marketing.

Wathne, K. H., Biong, H., \& Heide, J. B. (2001). Choice of supplier in embedded markets: relationship and marketing program effects. Journal of Marketing, 65(2), 54-66.

Wheelwright, S. C., \& Clark, K. B. (1992). Revolutionizing product development: quantum leaps in speed, efficiency, and quality: Simon and Schuster.

Whitten, D., \& Wakefield, R. L. (2006). Measuring switching costs in IT outsourcing services. The Journal of Strategic Information Systems, 15(3), 219-248.

Wright, J., Harrison, S., McGeorge, M., Patterson, C., Russell, I., Russell, D., .. . Warren, E. (2006). Improving the management and referral of patients with transient ischaemic attacks: a change strategy for a health community. BMJ Quality \& Safety, 15(1), 9-12.

Zeeshan, M., \& Obaid, M. H. (2013). Impact of Music on Consumer Behaviour: A Perspective on retail atmospheric. Asian Journal of Business and Management Sciences, 3(2), 56-63. 